\title{
Intensive Care Unit Telemedicine
}

Editor

KIANOUSH B. KASHANI

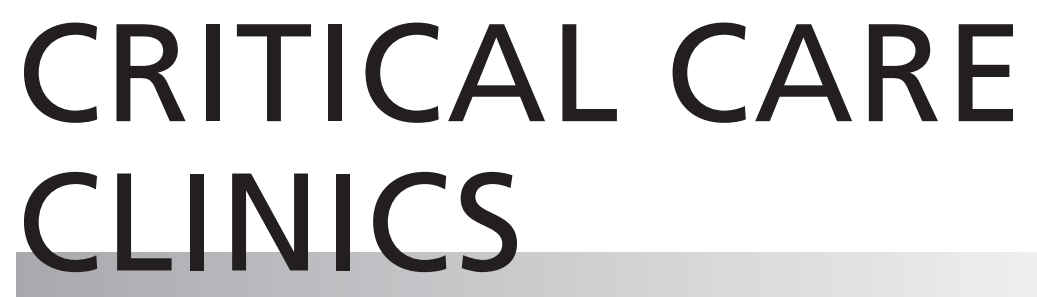

www.criticalcare.theclinics.com

Consulting Editor

JOHN A. KELLUM

July 2019 • Volume 35 • Number 3 